\title{
Comparison of Electrocautery and Ligasure Vessel Sealing System in Radial Artery Harvesting as Coronary Artery Bypass Surgery Conduit; A Randomized Trial
}

\author{
Eyup Okten ${ }^{1}$, Beril Okur ${ }^{2}$, Mehtap Akbaba ${ }^{2}$, Mert Dumantepe ${ }^{3}$, ŞAHIN ŞENAY ${ }^{2}$, and \\ Hasan Karabulut ${ }^{4}$ \\ ${ }^{1}$ Acibadem Kadikoy Hospital \\ ${ }^{2}$ Acibadem Universitesi \\ ${ }^{3}$ Dr.Siyami Ersek Cardiovascular Surgery Training and Research Hospital \\ ${ }^{4}$ Affiliation not available
}

November 2, 2020

\begin{abstract}
Background The radial artery (RA) is the second most used conduit in coronary artery bypass surgeries. The increased harvest of RA demands new approaches towards the use of this conduit. We aim to compare the efficiency of electrocautery with the vessel sealing system LigaSure. Materials and Methods This is a randomized trial comparing the use of LigaSure vessel sealing system and electrocautery in RA harvesting for coronary artery bypass surgery. Patients were randomly assigned into two groups. Group 1 consists of 27 patients operated with The LigaSure small jaw sealer/divider and Group 2 consists of 26 patients operated with electrocautery. Results During the study, 53 patients were operated. 44 of them were men and 9 of them were women. Difference between age and BMI were statistically insignificant. The amount of blood loss from the beginning of harvesting to the end of the closure of the skin of left arm was significantly less in group $1(p=0,004)$. The difference in number of hemostatic clips before and after the anastomosis of radial artery to coronary artery are likewise statistically significant and less in group $1(\mathrm{p}<0,001 ; \mathrm{p}<0,001$ respectively). The amount of blood loss postoperatively $(\mathrm{p}>0,6)$, number of ecchymoses $(\mathrm{p}>0,1)$, hematoma $(\mathrm{p}>0,1)$ and infection postoperatively $(\mathrm{p}>0,03)$ are found to be statistically insignificant. Conclusion The LigaSurevessel sealing system is found to be a better option of harvesting in patients that are prone to bleed.
\end{abstract}

\section{Comparison of Electrocautery and Ligasure Vessel Sealing System in Radial Artery Harvesting as Coronary Artery Bypass Surgery Conduit; A Randomized Trial}

Ökten, Murat $(\mathrm{PhD})^{1}$,Okur, Beril(MS ${ }^{2}$, Akbaba, Mehtap $(\mathrm{RN})^{3}$, Dumantepe, Mert $(\mathrm{PhD})^{1}$, Şenay, Şahin $(\mathrm{PhD})^{1}$, Karabulut, Hasan $(\mathrm{PhD})^{1}$

${ }^{1}$ Department of Cardiovascular Surgery, Acıbadem Mehmet Ali Aydınlar University, Istanbul, Turkey.

${ }^{2}$ Faculty of Medicine, Acıbadem Mehmet Ali Aydınlar University, Istanbul, Turkey.

${ }^{3}$ Department of Nursing, Acıbadem Mehmet Ali Aydınlar University, Istanbul, Turkey.

Running Title: Comparison of Electrocautery and LigaSure

Corresponding Author:

Beril Okur

Acibadem Mehmet Ali Aydınlar University School of Medicine 
Sarıyer-Istanbul

E-mail:berilokur@hotmail.com

Mobile: (+90) 7618082

Funding: None

Conflict of Interest: None

\section{Original Article}

\section{Word Count: 2197}

\section{Hosted file}

Abstract.pdf available at https://authorea.com/users/372321/articles/490417-comparisonof-electrocautery-and-ligasure-vessel-sealing-system-in-radial-artery-harvesting-ascoronary-artery-bypass-surgery-conduit-a-randomized-trial

\section{Hosted file}

Radial Artery Article Main.pdf available at https://authorea.com/users/372321/articles/ 490417-comparison-of-electrocautery-and-ligasure-vessel-sealing-system-in-radial-arteryharvesting-as-coronary-artery-bypass-surgery-conduit-a-randomized-trial

\section{Hosted file}

Table 1.pdf available at https://authorea.com/users/372321/articles/490417-comparisonof-electrocautery-and-ligasure-vessel-sealing-system-in-radial-artery-harvesting-ascoronary-artery-bypass-surgery-conduit-a-randomized-trial

\section{Hosted file}

Table 2.pdf available at https://authorea.com/users/372321/articles/490417-comparisonof-electrocautery-and-ligasure-vessel-sealing-system-in-radial-artery-harvesting-ascoronary-artery-bypass-surgery-conduit-a-randomized-trial

\section{Hosted file}

Table 3.pdf available at https://authorea.com/users/372321/articles/490417-comparisonof-electrocautery-and-ligasure-vessel-sealing-system-in-radial-artery-harvesting-ascoronary-artery-bypass-surgery-conduit-a-randomized-trial

\section{Hosted file}

Table 4.pdf available at https://authorea.com/users/372321/articles/490417-comparisonof-electrocautery-and-ligasure-vessel-sealing-system-in-radial-artery-harvesting-ascoronary-artery-bypass-surgery-conduit-a-randomized-trial 